\title{
SLOVENSKO PODEŽELJE IN NOVA STRATEGIJA RAZVOJA
}

\section{Tomaž Cunder}

Kmetijski inštitut Slovenije, Hacquetova 17, 1000 Ljubljana, Slovenija

e-mail: tomaz.cunder@kis.si

Izvirni znanstveni članek

COBISS 1.01

\section{Izvleček}

$\mathrm{V}$ prispevku je analiziran pomen politike razvoja podeželja $\mathrm{v}$ glavnih strateških dokumentih in izvedbenih ukrepih kmetijske politike. Kvalitativna analiza Nacionalnega strateškega načrta za programsko obdobje 2007 - 2013, ki zajema raven usklajenosti politike z razvojnimi potrebami in cilji, predstavlja okvir za kritično oceno sprejemljivosti posameznih ukrepov. Obseg in struktura finančnih sredstev, ki jih za različne spodbude namenja država, kažeta na izrazito povečan gospodarski, socialni in okoljski pomen razvoja slovenskega podeželja.

Ključne besede: razvoj podeželja, kmetijska politika, nacionalni strateški načrt, konkurenčnost, trajnostni razvoj, program LEADER

\section{SLOVENIAN RURAL AREAS AND NEW STRATEGY OF DEVELOPMENT}

\begin{abstract}
Importance of rural development policy in main strategic documents and implemental measures of agrarian policy in Slovenia is described. Qualitative evaluation of National Strategic Plan according to its consistency and reconciliation with identified needs and objectives presents a framework for critical estimation of acceptability of individual measures. The extent and structure of financial support offered to various aims by Slovenian Government point at increased economical, social and environmental interest of Slovenian countryside.
\end{abstract}

Key words: rural development, agricultural policy, national strategic plan, competitiveness, sustainability, programme LEADER 


\section{UVOD}

Slovenija se uvršča v krog držav z nadpovprečnim deležem podeželskih območij. Od skupno 193 občin se glede na gostoto prebivalstva kar dve tretjini uvrščata med podeželske. Ruralna območja predstavljajo okoli $75 \%$ celotnega ozemlja države in $40 \%$ vsega prebivalstva (MKGP 2006, 5). Razmeroma hitra deagrarizacija slovenskega podeželja in z njo povezana depopulacija sta $v$ Sloveniji že zgodaj povzročili velike ekonomske in demografske spremembe v podeželskem prostoru. Procesi diferenciacije podeželja so se odrazili v členitvi prvotno enotnega agrarnega podeželja v območja urbanizacije, prehodna območja in območja klasične agrarne pokrajine (Klemenčič, 2002, 8). Medtem ko v urbaniziranih agrarnih območjih in v območjih okoli večjih mest delež in pomen kmetijstva tako v demografskem kot tudi ekonomskem pogledu naglo nazaduje, pa se klasična ruralna območja še vedno soočajo s strukturnimi in razvojnimi problemi (slaba učinkovitost in nekonkurenčnost kmetijstva, opuščanje pridelave in zaraščanje kmetijskih zemljišč). Nezadostni dohodki za polno zaposlitev in s tem neprivlačnost kmetijstva na eni strani ter nemobilnost proizvodnih dejavnikov (predvsem zemlje in delovne sile) na drugi strani, tako ostajajo temeljni strukturni problemi v slovenskem kmetijstvu tudi po vstopu naše države v EU.

\section{METODOLOŠKA IZHODIŠČA}

V pričujočem prispevku so našteti vsi poglavitni dejavniki in razlogi za uvedbo evropsko primerljive politike razvoja podeželja v Sloveniji po letu 2004 ter ovrednoteni posamezni ukrepi kmetijske politike, ki predstavljajo ogrodje sistema spodbud za izboljšanje agrarne in regionalne strukture $\mathrm{v}$ ruralnih območjih. Poleg razmeroma podrobne analize sedanjih mehanizmov delovanja politike je namen prispevka tudi:

- $\quad$ kritična presoja (ocena) predlagane strategije razvoja podeželja v prihodnjem programskem obdobju 2007 - 2013 s posebnim poudarkom na njeni usklajenosti s predlaganimi razvojnimi cilji in identificiranimi potrebami;

- $\quad$ ocena možnih posledic (pozitivnih in negativnih) reformirane politike na gospodarski, socialni in okoljski položaj slovenskega podeželja.

Prispevek pretežno temelji na podrobni analizi razpoložljive literature, zakonodajno pravnih in strateških dokumentov ter razpoložljivih raziskovalnih študij. Poudarek je namenjen nekaterim ključnim mejnikom vzpostavljanja spremenjene politike razvoja podeželja $\mathrm{v}$ Sloveniji: pridružitvi EU v letu 2004 in Reformi kmetijske politike in politike razvoja podeželja v EU, ki bo stopila v veljavo z novim programskim obdobjem 2007 - 2013. Kritična ocena predvidene politike in posameznih ukrepov temelji na uporabi standardnih evalvacijskih metod, ki se uporabljajo pri vrednotenju podobnih strateških in razvojnih dokumentov. 


\section{SLOVENSKO PODEŽELJE IN POLITIKA RAZVOJA DANES}

Z vstopom v EU in prevzemom skupne zakonodaje so bile na področju kmetijske strukturne politike in politike razvoja podeželja v letu 2004 izvedene predvsem organizacijske, administrativne in pravne spremembe. $V$ procesu prilagajanja sta bila pripravljena dva temeljna strateško razvojna dokumenta:

- $\quad$ Program razvoja podeželja za Republiko Slovenijo 2004-2006 (PRP) in

- $\quad$ Enotni programski dokument Republike Slovenije 2004-2006 (EPD).

Dokumenta sta vsebinsko zasnovana tako, da predstavljata osnovo za celovito načrtovanje, izvajanje in spremljanje politike razvoja podeželja v Sloveniji. Zajemata različne strukturne ukrepe, ki so namenjeni ohranjanju in razvoju kmetijstva in z njim povezanih dejavnosti v ruralnem prostoru. S strani EU verificirani nacionalni programi in ukrepi so $\mathrm{z}$ različnimi deleži sofinancirani iz evropskega kmetijskega proračuna. Enotni programski dokument vsebinsko prevzema ukrepe, ki so bili predmet predpristopne pomoči EU v okviru programa SAPARD, kakor tudi velik del programa podpor prestrukturiranju kmetijstva in živilstva iz okvira nacionalnih ukrepov, ki so se izvajali pred vstopom v EU.

\section{I Program razvoja podeželja 2004-2006}

Ukrepi, zajeti v Programu razvoja podeželja za Republiko Slovenijo 2004-2006 (Ur. 1. RS, št. 116/04) so do 80 \% sofinancirani iz zagotovljenega dela Evropskega kmetijskega jamstvenega in usmerjevalnega sklada, vsaj $20 \%$ pa iz nacionalnega proračuna (MKGP 2004). Namenjeni so širokemu krogu upravičencev. Finančna sredstva se letno razdelijo na podlagi javnih razpisov, ki jih objavi Agencija RS za kmetijske trge in razvoj podeželja (ARSKTRP). Ukrepi zajemajo različne oblike plačil v okviru dveh prednostnih nalog:

- $\quad$ prednostna naloga 1 - sonaraven/trajnosten razvoj kmetijstva in podeželja, ki zajema izravnalna plačila za območja z omejenimi možnostmi za kmetijsko dejavnost (ukrep OMD) in kmetijsko okoljske ukrepe (ukrepi SKOP);

- $\quad$ prednostna naloga 2 - ekonomsko in socialno prestrukturiranje kmetijstva, ki zajema ukrep zgodnjega upokojevanja in podpore izvajanju EU standardov na kmetijskih gospodarstvih.

Za spremljanje, vrednotenje in preverjanje izvajanja ukrepov PRP ter izobraževanje in promocijo so znotraj druge prednostne naloge predvidena tudi finančna sredstva za tehnično pomoč v višini $2 \%$ vseh finančnih sredstev programa. Poleg tega je del sredstev iz okvira PRP namenjen programu SAPARD ter dopolnjevanju neposrednih plačil. Prva prednostna naloga (ukrep OMD, ukrepi SKOP) v bistvu pomeni nadaljevanje ukrepov, ki so bili v veljavi že pred vstopom v EU, medtem ko so ukrepi v okviru druge prednostne naloge za Slovenijo novi. 


\subsection{Enotni programski dokument 2004 - 2006}

Konec leta 2003 je bil sprejet Enotni programski dokument 2004-2006 (EPD), ki skupaj s Programskim dopolnilom Republike Slovenije za obdobje 2004-2006 določa, kako bo Slovenija v skladu s svojo dolgoročno strategijo in cilji porabila razpoložljiva sredstva iz strukturnih skladov, kohezijskega sklada in nacionalnega proračuna. Kmetijstvo je v EPD obravnavano v okviru tretje prednostne naloge $\mathrm{z}$ naslovom Prestrukturiranje kmetijstva, gozdarstva in ribištva. Strukturni ukrepi so sofinancirani iz usmerjevalnega dela evropskega kmetijskega proračuna, preostanek pa iz nacionalnega proračuna. Delež javnih sredstev, ki jih zagotovi Slovenija, znaša $50 \%$.

$\mathrm{V}$ okviru 3. prednostne naloge prestrukturiranje kmetijstva, gozdarstva in ribištva Slovenija v obdobju 2004-2006 izvaja 7 ukrepov (MKGP 2003). Od tega se en ukrep nanaša na področja gozdarstva (naložbe $\mathrm{v}$ gozdove za izboljšanje gospodarske in ekološke vrednosti gozdov), dva na področje ribištva (posodobitev obstoječih plovil in mali priobalni ribolov; ribogojstvo, predelava in trženje), s področja kmetijstva pa se izvajajo 4 ukrepi:

- izboljšanje predelave in trženja kmetijskih proizvodov;

- naložbe v kmetijska gospodarstva;

- diverzifikacija kmetijskih dejavnosti in dejavnosti, ki so blizu kmetijstvu in

- trženje kakovostnih kmetijskih in živilskih proizvodov.

Slika 1: Struktura proračunskih izdatkov za kmetijstvo v obdobju 1994-2004.

Figure 1: Structure of the budget expenditures for agriculture in the period $1994-2004$.

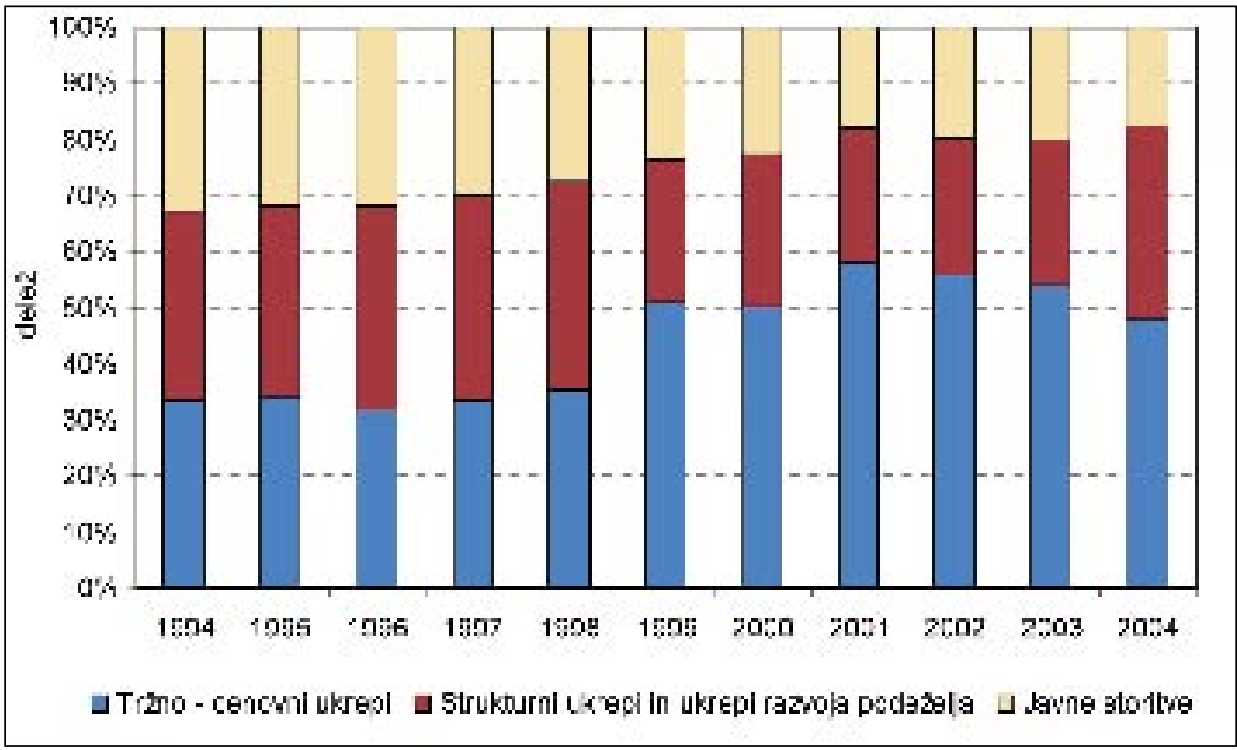

Vir:MKGP, KIS 


\subsection{Višina proračunskih sredstev}

Proračunski izdatki za podpore kmetijstvu so se v zadnjih desetih letih izrazito povečali (v obdobju 1994-2004 skoraj za sedem krat). To velja tako za ukrepe tržno cenovne politike, kot tudi za ukrepe strukturne politike in politike razvoja podeželja.

V obdobju 1994-1998 so proračunske podpore za ukrepe strukturne politike in politike razvoja podeželja $\mathrm{v}$ povprečju znašale okrog $35 \%$ skupnih izdatkov za podpore kmetijstvu. Ta delež je v obdobju 1999-2003 padel na okoli $25 \%$ (predvsem zaradi izrazitega povečanja proračunskih sredstev za neposredna plačila v okviru tržno cenovne politike), leta 2004 pa se je ponovno povečal na 34 \% (Bedrač in Cunder 2006, 253).

Slika 2: Delež izdatkov za posamezne skupine ukrepov v obdobju 1994 -2004.

Figure 2: Share of expenditures for individual groups of measures in the period 1994-2004.

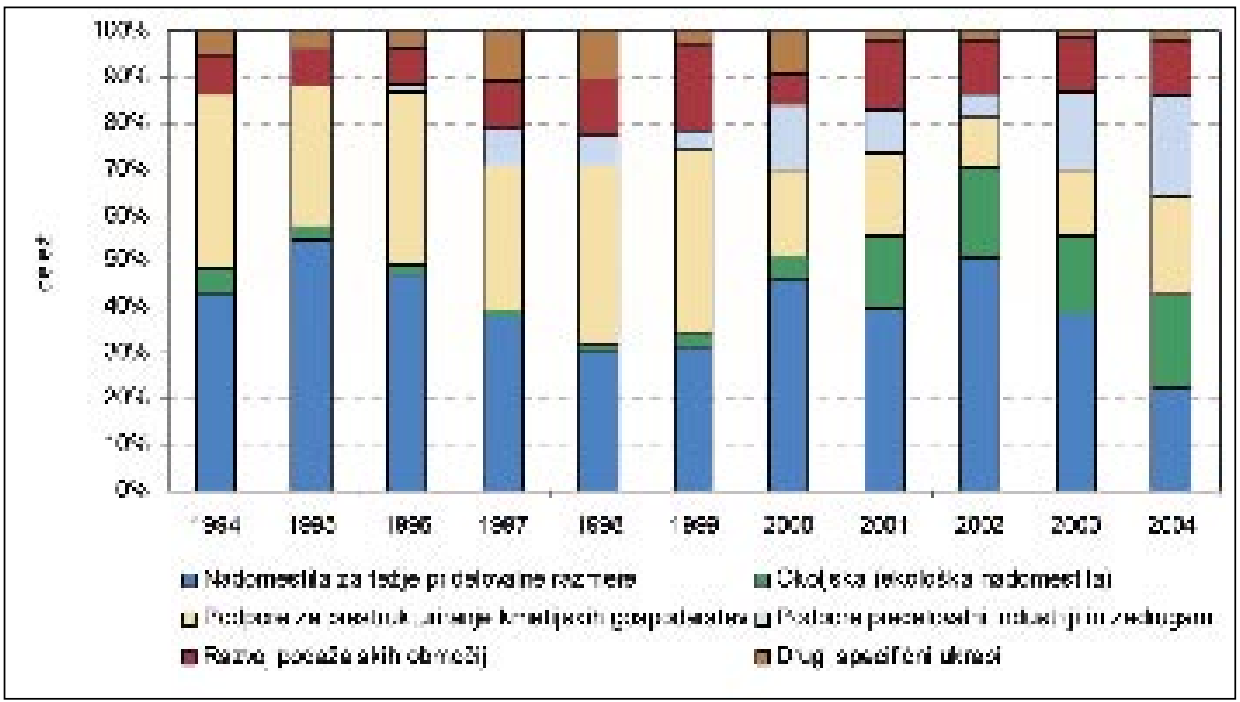

Vir:MKGP, KIS

Razmerje med posameznimi plačili znotraj strukturnega dela kmetijskega proračuna se je v obravnavanem obdobju precej spreminjalo. V zadnjem obdobju, predvsem pa po vstopu v EU, se je finančna struktura postopoma ustalila in uravnotežila. Nekaj manj kot polovica vseh finančnih sredstev se namenja ukrepom, ki zagotavljajo trajnostno rabo podeželskih območij (izravnalna plačila za območja s težjimi pridelovalnimi razmerami, krajinska in okoljska plačila), okoli 40 \% za strukturne spremembe v kmetijstvu in živilsko pridelovalni industriji in dobrih $10 \%$ za razvojne ukrepe v podeželskih območjih. 


\section{RAZVOJ PODEŽELJA V OBDOBJU 2007-2013}

Konferenca o prihodnosti ruralnega razvoja, ki je novembra 2003 potekala v Salzburgu v Avstriji, predstavlja enega ključnih mejnikov pri vzpostavljanju nove strategije razvoja podeželja na območju EU. Reforma, ki jo je v nadaljevanju za novo programsko obdobje 2007 - 2013 pripravila Evropska komisija, v veliki meri odseva potrebe posameznih regij in vseh ostalih, ki so vpleteni v razvoj podeželja. V konceptualnem smislu pomeni znaten napredek, ki se predvsem kaže v:

- $\quad$ poenostavitvi politike in upravno administrativnih postopkov;

- $\quad$ krepitvi pomena partnerstva pri pripravi in izvajanju programov razvoja podeželja;

- $\quad$ izpopolnjevanju izkušenj, pridobljenih iz programa LEADER;

- uvedbi enega programiranja, enega sistema financiranja, enega razvojnega finančnega sklada in enega sistema nadzora.

$\mathrm{Na}$ osnovi navedenega razvojnega koncepta so bili na novo opredeljeni tudi cilji politike razvoja podeželja, ki jih delimo na:

- $\quad$ izboljšanje konkurenčnosti kmetijskega sektorja s podporo prestrukturiranju,

- zagotavljanje varovanja okolja in podeželja z učinkovitim gospodarjenjem s kmetijskimi in gozdnimi zemljišči;

- $\quad$ povečanje kakovosti življenja na podeželju in spodbujanje diverzifikacije gospodarskih dejavnosti na podeželju.

Slika 3: Shema skupne politike EU za razvoj podeželja v obdobju 2007 - 20013.

Figure 3: Scheme of common agricultural policy for rural development in the period 2007 - 2013

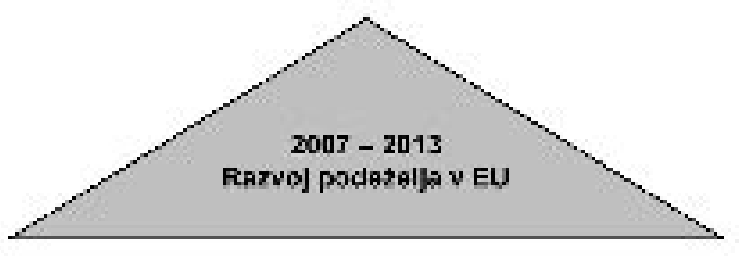

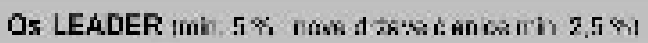
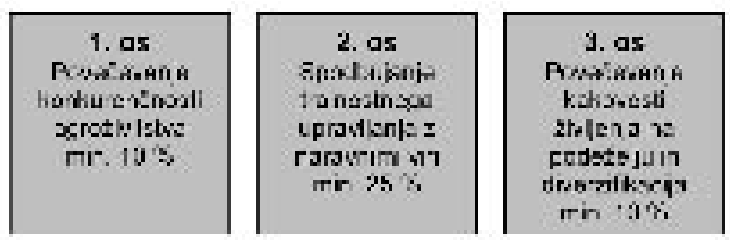

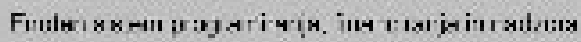

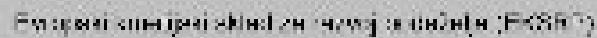


Cilji politike predstavljajo temelj za določitev treh glavnih razvojnih osi, v okviru katerih se bodo izvajali naslednji ukrepi:

- 1. os: Povečevanje konkurenčnosti agroživilstva

- $\quad$ Ukrepi za izboljšanje človeškega potenciala

- $\quad$ Ukrepi za prestrukturiranje kmetijstva in živilsko predelovalne industrije

- $\quad$ Ukrepi za izboljšanje kakovosti kmetijske proizvodnje in proizvodov

- $\quad$ Prehodni ukrepi za nove države članice

- 2. os: Spodbujanje trajnostnega upravljanja $z$ naravnimi viri

- $\quad$ Ukrepi za trajnostno rabo kmetijskih zemljišč

- $\quad$ Ukrepi za trajnostno rabo gozdnih zemljišč

- 3. os: Povečevanje kakovosti življenja na podeželju in ekonomska diverzifikacija

- $\quad$ Ukrepi za izboljšanje kakovosti na podeželju

- $\quad$ Ukrepi za razširitev gospodarskih dejavnosti na podeželju

Iniciativa LEADER, ki pravzaprav predstavlja 4. razvojno os, je opredeljena kot povezovalni člen razvojnih programov: vsaj del aktivnosti v okviru preostalih treh osi naj bi se izvajal po načinu LEADER. Nosilci izvajanja te iniciative so lokalne akcijske skupine (LAS), za usposabljanje in delovanje katerih so predvidena posebna finančna sredstva.

$\mathrm{Na}$ osnovi prikazanega strateškega koncepta in zakonske podlage (Uredbe sveta EU št. 1698/2005 o podpori za razvoj podeželja in Evropskega kmetijskega sklada za razvoj podeželja) so države članice dolžne v postopku programiranja pripraviti dva razvojna dokumenta:

- nacionalni strateški načrt in

- $\quad$ nacionalni ali regionalni program razvoja podeželja.

\section{KRITIČNA OCENA PREDLAGANEGA NACIONALNEGA STRATEŠKEGA NAČRTA}

Nacionalni strateški načrt razvoja podeželja (NSN) opredeljuje prednostne naloge na področju politike razvoja podeželja v Republiki Sloveniji (MKGP 2006, 4). Pripravljen je za programsko obdobje 2007 - 2013 in se bo izvajal na celotnem območju države. V njem so upoštevane tako širše strateške usmeritve EU na področju trajnostne rabe naravnih virov (sklepi sveta iz Göteborga) kot tudi strateške usmeritve o krepitvi gospodarske rasti in zaposlovanja (Lizbonska strategija).

Na splošno velja, da so prednostne naloge v NSN opredeljene tako, da je izpostavljen večnamenski pomen kmetijstva v ruralnih območjih. Pri tem so posebej izpostavljene:

- $\quad$ potrebe po prestrukturiranju kmetijstva in živilsko predelovalne industrije ter krepitvi konkurenčnosti celotnega agroživilskega sektorja;

- načela trajnostnega gospodarjenja z obnovljivimi naravnimi viri, ohranjanja kulturne pokrajine in varovanja okolja;

- večnamenska vloga gozdov, ki zaradi svoje razširjenosti slovenski pokrajini dajejo še poseben pečat in pomembno vplivajo na kvaliteto okolja in biotsko raznovrstnost; 
- ekonomski in socialni krepitvi podeželja, kjer se uveljavljajo nove možnosti za povečanje zaposlenosti na podeželju, in to ne samo $v$ kmetijstvu ampak tudi $v$ drugih gospodarskih dejavnostih.

Preglednica 1: Usklajenost NSN z identificiranimi potrebami in cilji ter ocena sprejemljivosti ukrepov. Table 1: Reconciliation of NSP with identified needs and aims and acceptability of measures.

\begin{tabular}{|c|c|c|c|c|}
\hline \multirow[b]{2}{*}{$\begin{array}{l}\text { Razvojne osi } \\
\begin{array}{l}\text { - } \\
\text { Prednostne naloge } \\
-\quad \text { Aktivnosti (ukrepi) }\end{array}\end{array}$} & \multicolumn{2}{|c|}{$\begin{array}{c}\text { Usklajenost ukrepov } \\
\text { z vidika: }\end{array}$} & \multirow{2}{*}{ 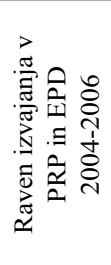 } & \multirow{2}{*}{ 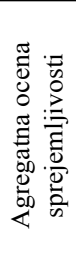 } \\
\hline & 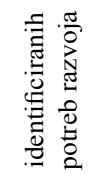 & 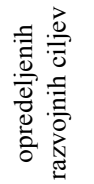 & & \\
\hline 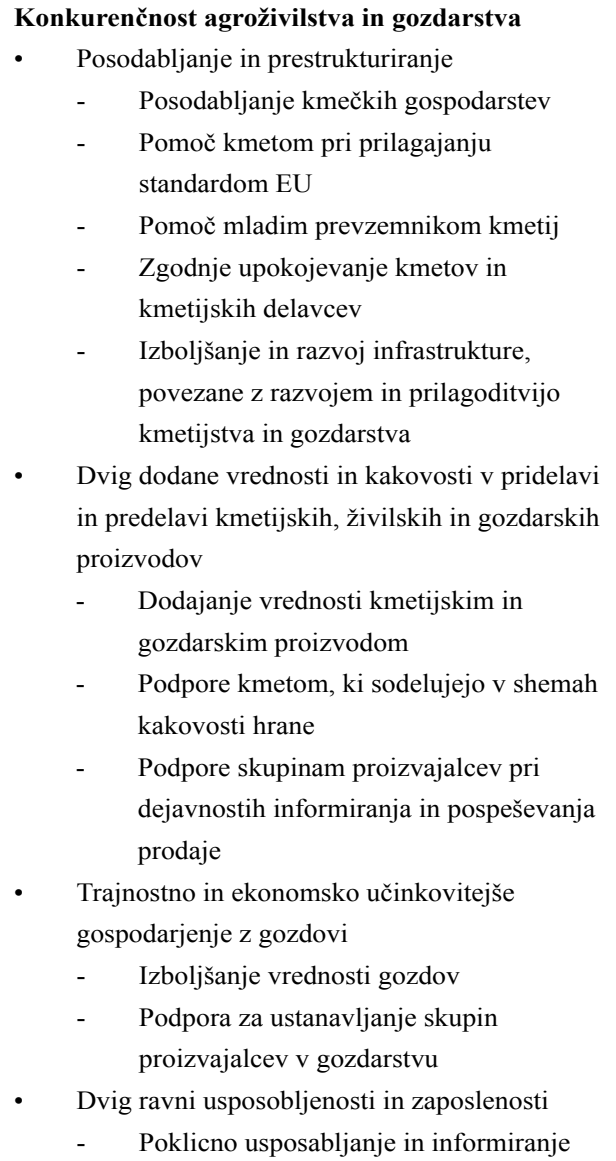 & $\begin{array}{l}++ \\
++ \\
-\end{array}$ & $\begin{array}{l}+ \\
++ \\
+\end{array}$ & $\begin{array}{l}+ \\
+\end{array}$ & $\begin{array}{c}++ \\
++ \\
+ \\
+\end{array}$ \\
\hline
\end{tabular}




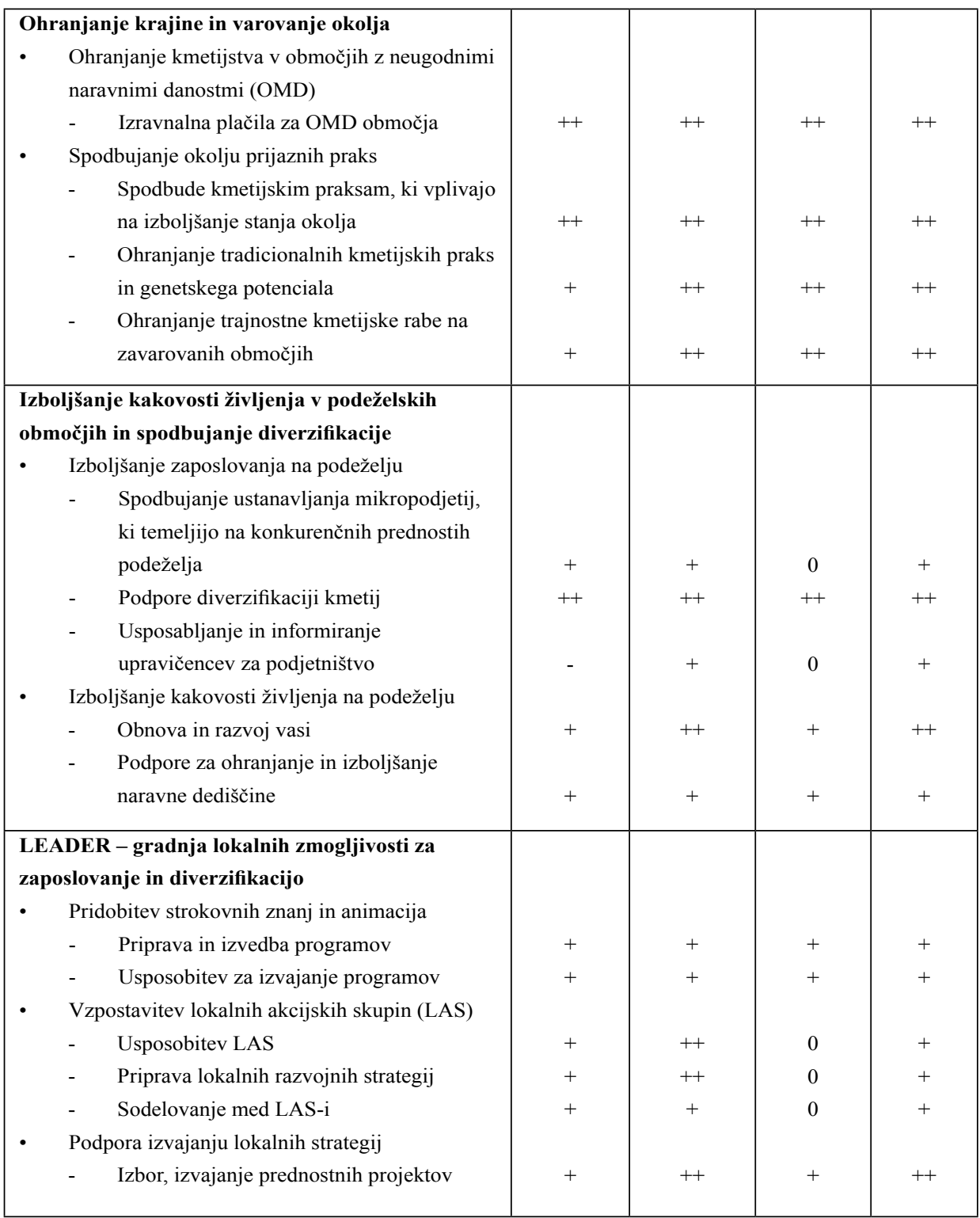

Raven usklajenosti: ++ (popolna usklajenost), + (delna usklajenost) - (neusklajenost)

Raven izvajanja v PRP 2004-2006: ++ (popolno izvajanje). + (delno izvajanje) - (ukrep se ni izvajal) Raven agregatne sprejemljivosti: ++ (popolna sprejemljivost), + (delna sprejemljivost, izvajanje v omejenem obsegu), 
Usklajenost predlaganih ukrepov $\mathrm{z}$ vidika identificiranih potreb bistveno ne odstopa od usklajenosti z vidika opredeljenih razvojnih ciljev. To pomeni, da so bili pri pripravi strategije primerno upoštevani tako obstoječe stanje (naravne in strukturne danosti, stanje okolja, človeški viri, aktualna kmetijska politika), kot tudi razvojni potenciali in specifične potrebe za uresničevanje nacionalnih ciljev. V tem pogledu še posebej izstopa 2. razvojna os, kjer je zaradi preteklih izkušenj z izvajanjem ukrepov, predvsem pa zaradi prostorske razpršenosti ukrepanja, raven strateške usklajenosti najvišja. To se posledično odraža tudi na agregatni ravni sprejemljivosti ukrepov, pa tudi na razporejanju finančnih sredstev po posameznih razvojnih oseh in prednostnih nalogah.

Za dvig konkurenčnosti kmetijskega in gozdnega sektorja bo Slovenija po NSN namenila okoli $34 \%$ vseh sredstev. To je precej več, kot znaša minimalni priporočeni delež s strani EU in tudi precej več kot je Slovenija doslej namenjala za ta del strukturne politike. Zaradi velikih razvojnih potreb po prestrukturiranju ter zaostajanja v konkurenčnosti pa je tako povečanje pravzaprav nujno. Kar okoli $53 \%$ sredstev bo namenjenih za ohranjanje krajine in okolja, saj le takšen obseg sredstev zagotavlja neprekinjenost izvajanja kmetijsko okoljskih ukrepov in obdelanost kmetijskih zemljišč v območjih z omejenimi dejavniki za kmetovanje. Nekaj več kot 10 \% sredstev bo namenjenih za izboljšanje kakovosti življenja na podeželju in diverzifikacijo podeželskega gospodarstva (MKGP 2006, 13).

Ravnovesje med tremi ključnimi področji ukrepanja po razvojnih oseh je v NSN tako z vsebinskega kot tudi finančnega vidika vsekakor doseženo. Zastavlja pa se vprašanje, ali so v strateškem dokumentu enakovredno zastopani vsi vidiki razvoja slovenskega podeželja in ali so $\mathrm{s}$ predlagano strategijo dejansko zasledovani cilji večnamenskosti kmetijstva $\mathrm{v}$ podeželskem prostoru. Trdimo lahko, da imata tako gospodarski kot tudi okoljski vidik v strateškem dokumentu ustrezno težo, $s$ tem pa so ustrezno zagotovljeni tudi proizvodni in okoljski elementi večnamenskosti. Glede na še vedno prisotno depopulacijo na za življenje in gospodarjenje marginalnih območij in posledično zmanjševanje obsega kmetijskih zemljišč pa lahko trdimo, da ukrepi v smislu zasledovanja socialnih, predvsem pa prostorskih elementov večnamenskosti večinoma verjetno ne bodo dovolj učinkoviti.

\section{SKLEPNE MISLI}

Uspeh izvajanja politike razvoja podeželja v programskem obdobju 2007- 2013 bo vsekakor odvisen od mnogih dejavnikov. Poleg uspešne priprave razvojnih programov in ustreznega obsega razpoložljivih finančnih sredstev so to vsekakor ustrezna administrativna struktura, in učinkovito informiranje ciljne populacije (Cunder 2003, 2). Tudi povezovanje $\mathrm{z}$ drugimi ukrepi skupne kmetijske politike ima pomembno vlogo, predvsem $\mathrm{v}$ smislu zasledovanja večnamenskih ciljev glede okolja in obdelanosti agrarne pokrajine. Ključno vlogo za uspeh pa ima skrbno spremljanje učinkovitosti izvajanja posameznih ukrepov, kjer je potrebno vzpostaviti ustrezen sistem indikatorjev, ki bodo odražali tako gospodarske kot tudi prostorske, socialne in okoljske učinke izvajanja političnih instrumentov.

$\mathrm{Na}$ koncu moramo poudariti, da je za uspešno ohranjanje poseljenosti in pospeševanje razvoja podeželskih območij nujno sočasno ter koordinirano uvajanje in delovanje različnih 
gospodarskih aktivnosti. Pri tem mora biti zagotovljena:

- dolgoročnost ukrepov agrarne, socialne, regionalne in naravovarstvene politike;

- močnejše in predvsem obvezno vključevanje vodilnih dejavnosti (kmetijstva, gozdarstva) v regionalno politične odločitve, programe in dejanja;

- dolgoročnost politike zaposlovanja, predvsem v smislu zagotavljanja novih delovnih mest;

\section{Literatura in viri}

Bedrač, M., Cunder, T. 2006: Slovenska kmetijska politika in večnamenskost kmetijstva = Slovenian agricultural policy and multifunctional role of agriculture. V: Kavčič, S., (ur.). 3. konferenca DAES, Moravske Toplice, Slovenija v EU - izzivi za kmetijstvo, živilstvo in podeželje. 1. izd. Ljubljana: Društvo agrarnih ekonomistov Slovenije, str. 243-257,

Cunder, T. 2003, Reform of the rural development policy in Slovenia - challenges and dilemmas. V: EU-Enlargement - chances and risks for the rural area, Ljubljana, 8 str.

Klemenčič, V. 2002, Procesi deagrarizacije in urbanizacije slovenskega podeželja = Processes of deagrarization and urbanization of Slovene rural Areas, Dela 17, Oddelek za geografijo Filozofske fakultete, Ljubljana, str. 7-21

Ministrstvo za kmetijstvo, gozdarstvo in prehrano (MKGP). 2004, Program razvoja podeželja za Republiko Slovenijo 2004-2006, Ljubljana, 205 str.

Ministrstvo za kmetijstvo, gozdarstvo in prehrano (MKGP). 2006, Nacionalni strateški načrt razvoja podeželja 2007-2013, Ljubljana, 38 str.

Vlada Republike Slovenije. 2003, Enotni programski dokument 2004-2006(EPD), Ljubljana, str. 172-197

\section{SLOVENIAN RURAL AREAS AND NEW STRATEGY OF DEVELOPMENT}

\section{Summary}

Rural development policy was one of the key issues and priorities for Slovenia on its way to European Union. The Rural Development Policy, which is created under the framework of EU rules, comprises several measures, which are to be co-financed by the EU funds. They contribute to environmentally, socially and economically sustainable development of rural areas in Slovenia.

The paper briefly outlines theoretical arguments for introducing of EU comparable rural development policy and examines the implementation of different support measures in Slovenian agricultural policy. The objectives of the paper are:

- to analyse the principles of current rural development policy in Slovenia and to expose the crucial points of policy support in Slovenia and EU;

- to carry out critical assessment (evaluation) of the proposed National Strategic Plan (NSP) 
for the period 2007 - 2013 with special emphasis on its consistency and reconciliation with identified needs, aims and means;

- to point on possible consequences - positive or negative - of reformed policy on economical, social and environmental structure in Slovenia.

The paper is based on desk research drawing from responsible literature, legislation documents and available research studies. Emphasis is given to the two crucial milestones:

- $\quad$ accession of Slovenia and its agriculture into EU in 2004 and

- CAP Reform, which was discussed in EU in 2005 and will come into force in the new programming period 2007-2013.

No modelling work was elaborated in the framework of analyse. Critical evaluation is carried out in alignment with generally used and known policy evaluation techniques.

Reconciliation of proposed measures with identified needs does not deviate significantly from reconciliation of determinated developmental aims. By preparing of the Strategy the current situation (natural and structural conditions, environmental conditions, human resources and actual agricultural policy) as well as developmental potential and specific needs of rural areas in Slovenia have been appropriate taken into consideration. From the financial point of view balance between three main developmental axes of activity is definitely achieved.

A successful implementation of the National Strategic Plan and Rural Development Programme (RDP) in Slovenia in period 2007-2013 depends of many items including administrative structure, provision of information, monitoring of progress, integration with other policy objectives and the financial resources available. Programme which will be prepared under EU comparable regulations will have multiple objectives regarding environment and landscape. However, it will also have some economic and social objectives, which often bring competition between different policy interests. The rural development objectives might not be fully achieved in case when measures are taken without sufficient coordination with other CAP measures. A careful monitoring effort - also by introducing rural development indicators, will be needed to asses incentive payment schemes for their success in achieving of planning objectives and their effectiveness as policy instruments.

Insufficient income for fulltime employment and along with a lack of attractiveness of agriculture on one hand and immobility of production factors (mainly land and labour force) on the other, represent basic structural problems of the Slovene agriculture also after its accession to EU. In order to revitalise and accelerate the economic and social development of rural areas in Slovenia, simultaneous and co-ordinated promotion of various support activities is needed. Measures, involved in Slovenian rural development programme, could be effectively implemented only in the situation(s) where the following policy aspects can be ensured:

- further promotion of "non production" functions of agriculture in Slovene rural areas,

- complete integration of agriculture inside the current political system, programmes and occurrences,

- assurance of quality-environment as a basis for sustainable economic development,

- adoption of long-run agricultural, social, regional and ecological policies. 